\title{
ORIGINAL
}

ARTICLES

\section{Community Health Center Residency Training: Improving Staffing, Service, and Quality}

Candice Chen, MD, MPH; Nicholas Chong, MPH; Qian Luo, PhD, MPSA; Jeongyoung Park, PhD, MPH

\begin{abstract}
BACKGROUND AND OBJECTIVES: Community-based residency programs are an important strategy to address rural and underserved primary care shortages, however, health centers report both benefits and challenges to training. This study aims to understand the impact of new Teaching Health Center (THC) residency programs on health center staffing, patient service, quality of care, and provider productivity.
\end{abstract}

METHODS: Using the Uniform Data System, we used inverse propensity score weighting to create a balanced sample of new THC and non-THC health centers in 2010. Using 2018 data, we applied propensity score weighted regressions to examine changes in staffing, service, quality of care, and productivity in THC versus non-THC health centers.

RESULTS: In 2018, health centers with new THC programs were associated with increased physician $(16.40, P<.01)$ staffing, yet decreased physician visits per full-time equivalent $(-425.3, P<.01)$ relative to non-THC centers. New THC centers had increased delivery visits $(231.0, P<.05)$, and had a greater rate of early entry into prenatal care $(4.90 \%, P<.01)$.

CONCLUSIONS: New residency programs are associated with increased provider recruitment, expanded patient service, and some improved health outcomes, but also with potential decreased provider productivity in health centers.

(Fam Med. 2021;53(8):689-96.)

doi: 10.22454/FamMed.2021.843335

$\mathbf{R}$ ural and underserved primary care shortages persist in the United States. An estimated 80 million people live in primary care Health Professional Shortage Areas ${ }^{1}$ and community health centers-a critical component of the health care safety net-consistently report difficulty recruiting health care providers, identifying family physicians as one of the most difficult positions to fill. ${ }^{2}$ Community-based residency programs are an important strategy to address critical workforce needs. Evidence demonstrates residents who train in community health centers and other safety net settings are more likely to work in underserved settings..$^{3-5}$

Health centers engaged in residency training report both benefits and challenges with training residents. While workforce recruitment is often reported as a primary motivator, health centers report additional benefits to training, including expanded patient services (eg, women's health and behavioral health services) to meet accreditation requirements or related to new faculty recruitment and improved quality of care as residents require teaching faculty to stay up to date and evidencebased. ${ }^{6}$ However, health centers also report challenges in sustaining residency training due to concerns over financial viability, the effect of training on patient service particularly where revenue is based on patient visits, and the administrative challenges of meeting both community health center and residency program requirements. ${ }^{7,8}$

Financial barriers to health center-based residency programs include both start-up and sustainability costs. The estimated cost of starting a new residency program is between $\$ 350,000$ and $\$ 750,000,{ }^{9,10}$ and analysis of residency program accreditation requirements suggests smaller, outpatient-focused programs may actually cost more per resident due to economies of scale. ${ }^{11}$ Health centers are also disadvantaged in directly receiving Medicare graduate medical education (GME) funds, as the larger of two payments (indirect GME), is tied to inpatient service, and the other (direct GME), is based on

From the Fitzhugh Mullan Institute for Health Workforce Equity, Department of Health Policy and Management, Milken Institute School of Public Health, George Washington University, Washington, DC (Drs Chen and Luo, and Mr Chong); and George Washington University School of Nursing, Washington, DC (Dr Park). 
Medicare patient ratios, which are generally lower in the outpatient than inpatient setting. As a result, training in health center settings has remained limited. One study found only 48 family medicine and 43 internal medicine-reported federally qualified health center (FQHC), rural health clinic, or Indian Health Service training sites-3.5\% and $4.6 \%$ of all family medicine and internal medicine training sites, respectively. ${ }^{12}$ In another study, $23 \%$ (83 of 354) of family medicine residency programs reported some type of health center training experience, however, only 32 programs had their main continuity site in a health center. $^{13}$

In response to these challenges, the Teaching Health Center (THC) program was established in the Affordable Care Act to explicitly support new and expanded community-based primary care residency programs. The first class of residents supported by the THC program began in 2011 and the program currently supports 60 primary care residencies across 25 states. ${ }^{14}$ THCs are predominantly family medicine programs located in community health centers, rural health clinics, and tribal health centers, ${ }^{15}$ and they are showing promising outcomes with greater retention of THC graduates in primary care and underserved practice compared to national averages. ${ }^{16,17}$ The THC program also provides the opportunity to examine the reported benefits and challenges to starting residency programs in community health center settings.

Given the reported benefits and challenges to community-based residency training, we sought to examine changes in staffing, patient service, provider productivity, and quality of care of health centers that started new THC residency programs compared to non-THC health centers in 2018. We also examined the extent of Medicare GME payments to health centers. Better understanding these community-based residency programs is important for health center decision-making, as well as
GME programs and policies aimed at increasing the primary care workforce for underserved communities.

\section{Methods}

\section{Data and Sample}

In the main analysis, we identified health centers engaged in residency training through the publicly available Health Resources and Services Administration (HRSA) THC-funded program list. We found health centers associated with the THC residency programs through online searches and review of residency program websites. We categorized THCs as "new" or "expansion" programs using Accreditation Council for Graduate Medical Education information original accreditation date. As the first THC awards were made in 2011, new programs are those with original accreditation dates in or after 2011, while expansion programs had original accreditation dates prior to 2011, indicating they used THC awards to expand existing programs. We focus our analysis on new programs as our outcome measures of interest are related to the tenure of the residency program. For example, new programs have greater potential for growth related to the residency program than established programs that used the THC grant to marginally expand their resident numbers. From our primary data source, the HRSA Uniform Data System (UDS), we identified 1,134 total centers that existed in both 2010 and 2018. We excluded two new THCs due to program closures during the study period, which resulted in our final analytical sample, after employing our propensity score weighting strategy, of 22 health centers with new THC programs and 968 nonTHC health centers.

Our primary data source was the HRSA UDS. All community health centers that receive Section 330 grants under the Public Health Service Act report information on staffing, utilization, quality of care, center financials, and patient characteristics to the UDS on an annual basis. We examined three categories of outcome variables. The first was staffing capacity-physician, advanced practice clinician, nurse, other medical, and mental health full-time equivalents (FTEs), for which we calculated physician and total medical visits per FTE to assess the productivity of providers. The second variable we examined was select service lines-annual visit numbers for mental health (alcohol-related disorders, other substance-related disorders, depression, and other mental disorders) and women's health care (contraceptive management and deliveries). The third outcome variable was quality outcomes. This variable included the reported measures of controlled hypertension and controlled diabetes, which are consistently reported in the UDS from 2010 to 2018, and low birth weight and early entry into prenatal care outcomes, though these were unavailable in the 2010 UDS.

For our staffing capacity measures, we used reported FTE available in the UDS for each provider category. Relevant to THC programs, we noted that resident FTE are included in the overall reported physician FTE. For service lines, we compared visit and patient numbers and found them highly correlated, therefore we present our results as visits. Controlled hypertension and controlled diabetes represented the percentage of patients with a diagnosis who were adequately controlled. For both measures, an increase indicated an improvement for a center on these metrics. Alternatively, the low-birth-weight variable calculated the percentage of prenatal care patient babies whose birth weights were less than 2,500 grams. For this measure, a decrease in a center's percentage reflected an improvement for the outcome measure. A fourth quality metric, related to maternity care, was the percentage of prenatal care patients who entered care during their first trimester. Low birth weight and early entry into prenatal care were included due to qualitative reports of increased women's health care services. The total analytical sample of 990 reduced to 638 for the two regressions involving the measures of low birth weight and 
early entry into prenatal care, due to the exclusion of health centers reporting no births or prenatal care. These measures also did not exist in the baseline 2010 UDS and therefore were not included in the weighting process.

In a secondary analysis, we explored 2018 FQHC cost reports, extracted from the Healthcare Provider Cost Reporting Information System, to identify resident FTE in health centers with THC programs. Health centers submitting for Medicare GME payments would be required to report resident FTE. Each FQHC cost report varies significantly on the number of FQHC sites and the time period of the reports. As a result, we standardized the cost report data into the site calendar year level as a weighted sum of the original cost report entries using the proportion of the calendar year covered by the cost report as the weights. However, review of FQHC cost reports demonstrated inconsistent residency training reporting by known THC health centers, which may be related to minimal Medicare GME support to health center settings. We provide a brief descriptive analysis of Medicare GME support to FQHCs.

\section{Analysis}

We first employed an inverse propensity score weighting strategy based on center characteristics and the outcome variables of interest in 2010 to generate weights for a balanced sample of the new THC and nonTHC groups. The balanced sample allowed us to have an unconfounded comparison of the two groups in 2018. We used 2010 UDS data as a baseline year since it preceded the establishment of THC-funded programs, and applied a logistic regression match strategy to generate propensity scores for each new THC and non-THC programs based on health center and county characteristics and our outcomes variable, although we were unable to match on the low birth weight and earlyentry prenatal care outcomes, which were unavailable in 2010. By using both center-level and county-level characteristics in both the propensity score estimation and regressions, we used doubly robust estimators. County-level rates of diabetes and HIV are from the 2018 County Health Rankings. We then trimmed the sample of any outliers greater than $99.9 \%$ and less than $0.1 \%$ of the propensity score. Using inverse weighting of the generated propensity scores, we established a balanced sample for 22 new THCs and 968 non-THCs in 2010.

To model the difference in health centers with new THC programs compared to non-THCs, we used propensity score weights using 2010 data to regress the outcomes measures in 2018. This allowed us to observe differences in the outcomes in 2018 between new THC and nonTHC health centers based on a 2010 baseline where the two groups were balanced. We added health centerlevel and county-level characteristics to the model as control variables, including center patient demographics, rurality, and county-level diabetes and HIV prevalence rates. Regression models for the low birth weight and early entry into prenatal care outcome measures were limited to health centers reporting these outcomes (638 health centers), as not all health centers reported prenatal care outcomes.

We performed all statistical analyses using Stata SE 14.2 (Stata Corp, College Station, TX).

\section{Results}

The propensity score weights allowed us to generate a balanced sample of 22 new THC health centers and 968 non-THC health centers in 2010. We present the results of the inverse propensity score weighting strategy in Table 1 . After weighting, new THCs and non-THCs significantly differed only by the volume of substance use disorder services and alcohol treatment services provided. The weights matched all other outcomes variables of interest and control covariates in 2010 , before the establishment of the first THC program. Table 2 provides unweighted summary statistics of the outcome variables in 2018 for the analytical sample. The 22 THC health centers were predominantly associated with family medicine residency programs -17 family medicine, three internal medicine, one with family medicine and psychiatry, and one with family medicine and general dentistry.

\section{Staffing Capacity}

Applying the 2010 propensity score weights to 2018 data, we found that new THCs were associated with a statistically significant increase in the number of physician FTEs by $16.40(P<.01)$ compared to nonTHCs (Table 3). Relative increases in advance practice clinicians, nurses, mental health providers, and other medical providers FTE were also larger, however, the differences were not statistically significant. New THC programs were also associated with having more total visits by 33,415 visits per year relative to non-THCs at their 2010 baseline, though not statistically significant. However, despite the reported relative growth in new THC staffing and visits compared to non-THCs, there was a statistically significant decrease in the productivity of the new THCs. Health centers with new THCs were associated with having 425.3 fewer physician visits per FTE $(P<.01)$ compared to non-THC centers relative to the 2010 baseline.

\section{Service Lines}

The regression results for the changes in the service lines provided are presented in Table 4. We found that centers with new THC programs were associated with statistically significant higher volume of service visits for deliveries by 231.0 visits $(P<.05)$ compared to non-THCs (Table 4). Visits for substance use disorder, alcohol treatment, depression, other mental health, and contraception were all greater but not statistically significant.

\section{Quality Outcomes}

Controlled hypertension, controlled diabetes, low birth weight, and early entry into prenatal care outcomes 
Table 1: Propensity Score Match Weighted and Unweighted Summary Statistics of Matching Variables for New THC and Non-THC Groups in 2010

\begin{tabular}{|c|c|c|c|c|c|c|}
\hline & \multicolumn{3}{|c|}{ PSM Weighted } & \multicolumn{3}{|c|}{ Unweighted } \\
\hline & New THC & Non-THC & $t$ Test & New THC & Non-THC & $t$ Test \\
\hline Percent located in rural (\%) & 71.86 & 47.41 & 1.492 & 40.91 & 47.31 & -0.603 \\
\hline \multicolumn{7}{|l|}{ Percent of Patients (\%) } \\
\hline Minority status & 52.55 & 47.78 & 0.531 & 50.03 & 47.85 & 0.330 \\
\hline Low income & 91.89 & 92.33 & -0.139 & 89.47 & 92.39 & -0.764 \\
\hline Medicaid & 32.90 & 33.33 & -0.061 & 40.82 & 33.21 & $2.822^{* *}$ \\
\hline Uninsured & 43.76 & 39.98 & 0.515 & 30.91 & 40.14 & $-2.497^{*}$ \\
\hline \multicolumn{7}{|l|}{ FTEs } \\
\hline Physician & 8.3 & 8.7 & -0.119 & 30.4 & 8.5 & $4.321^{* *}$ \\
\hline $\mathrm{APC}$ & 7.1 & 5.9 & 0.633 & 16.8 & 5.8 & $4.196^{* *}$ \\
\hline Nurse & 10.0 & 10.1 & -0.026 & 33.2 & 9.9 & $3.344^{* *}$ \\
\hline Other medical & 14.5 & 15.5 & -0.148 & 54.9 & 15.2 & $4.065^{* * *}$ \\
\hline MH/SUD & 2.8 & 4.7 & -1.180 & 18.7 & 4.6 & $2.461^{*}$ \\
\hline Physician visits/FTE & $3,382.3$ & $3,685.0$ & -0.978 & $3,567.1$ & $3,687.7$ & -0.506 \\
\hline Total medical visits/FTE & $3,143.1$ & $3,176.0$ & -0.100 & $3,374.0$ & $3,173.7$ & 1.358 \\
\hline \multicolumn{7}{|l|}{ Visits by Service Lines } \\
\hline SUD & 131.4 & 643.8 & $-4.079 * *$ & $1,398.6$ & 643.8 & 1.511 \\
\hline Alcohol & 97.0 & 286.7 & $-2.583^{* *}$ & 917.2 & 279.8 & 1.753 \\
\hline Depression & $1,859.2$ & $3,041.1$ & -1.569 & $11,001.6$ & $2,984.2$ & $2.710^{* *}$ \\
\hline Other MH & 938.9 & $1,792.2$ & -0.669 & $5,511.3$ & $1,154.2$ & $2.430^{*}$ \\
\hline Contraceptives & $1,625.3$ & $1,792.2$ & -0.184 & $5,623.2$ & $1,774.0$ & $2.296^{*}$ \\
\hline Deliveries & 181.0 & 155.0 & 0.181 & 693.0 & 150.1 & $2.888^{* *}$ \\
\hline Total visits & $68,102.5$ & $69,916.7$ & -0.083 & $245,820.7$ & $68,490.5$ & $4.377^{* * *}$ \\
\hline \multicolumn{7}{|l|}{ Quality Outcomes (\% of Patients) } \\
\hline Controlled hypertension & 59.50 & 62.59 & -1.405 & 66.16 & 62.54 & 1.556 \\
\hline Controlled diabetes & 68.58 & 71.24 & -1.325 & 68.68 & 71.23 & -1.110 \\
\hline \multicolumn{7}{|l|}{ Financials } \\
\hline $\begin{array}{l}\text { Percent revenue from Medicaid } \\
(\%)\end{array}$ & 0.31 & 0.30 & 0.176 & 0.40 & 0.30 & $3.481^{* * *}$ \\
\hline Total revenue per patient & 586.48 & 684.69 & -1.529 & 714.48 & 684.56 & 0.682 \\
\hline HIV Prevalence (County) & 264.03 & 356.65 & -1.988 & 518.70 & 357.06 & 1.200 \\
\hline Diabetes Prevalence (County) & 0.11 & 0.10 & 0.694 & 0.09 & 0.10 & $-2.227 *$ \\
\hline Health Centers (n) & 22 & 968 & & 22 & 968 & \\
\hline
\end{tabular}

Abbreviations: PSM, propensity score match; THC, teaching health center; FTE, full-time equivalent; APC, advanced practice clinicians; MH, mental health; SUD, substance use disorder; FQHC, federally qualified health centers.

$* P<.05$.

** $P<.01$.

were all better in new THCs compared to non-THCs (Table 5). However, only early entry into prenatal care was statistically significant with 4.90 percent $(P<.01)$ more prenatal care patients entering early care in new THCs compared to non-THCs in 2018.

\section{Medicare GME Payments}

In 2018, we identified 2,385 unique centers in the FQHC cost reports. Thirteen centers reported allowable direct GME costs for Medicare reimbursements, of which, nine health centers reported training residents in an approved GME program under Medicare authority. Allowable direct GME costs for the nine health center residency programs ranged from $\$ 6$ 
Table 2: Summary Statistic of Analytical Outcome Variables for New Teaching Health Centers (THC) and Non-THCs in 2018

\begin{tabular}{|c|c|c|}
\hline & New THC (SD) & Non-THC (SD) \\
\hline \multicolumn{3}{|l|}{ FTEs } \\
\hline Physician & $50.1(35.8)$ & $10.5(16.4)$ \\
\hline $\mathrm{APC}$ & $30.1(24.5)$ & $11.6(11.2)$ \\
\hline Nurse & $50.4(52.0)$ & $15.0(18.9)$ \\
\hline Other medical & $101.9(76.8)$ & $27.2(38.7)$ \\
\hline MH/SUD & $45.0(48.2)$ & $10.5(21.5)$ \\
\hline \multicolumn{3}{|l|}{ Visits per FTE } \\
\hline Physician & $2,541.8(631.1)$ & $2,816.1(960.6)$ \\
\hline Total & 2,559.1 (531.6) & $2,626.7(713.0)$ \\
\hline \multicolumn{3}{|l|}{ Service Lines (Visits) } \\
\hline SUD & $8,039(12,975)$ & $2,025(5,585)$ \\
\hline Alcohol & $3,869(4,900)$ & $899(2,409)$ \\
\hline Depression & $51,327(51,804)$ & $12,373(19,691)$ \\
\hline Other MH & $20,524(25,742)$ & $4,064(7,854)$ \\
\hline Contraceptive & $8,353(8,135)$ & $2,278(3,510)$ \\
\hline Deliveries & $732(936)$ & $144(345)$ \\
\hline \multicolumn{3}{|l|}{ Quality Outcomes (\% of Patients) } \\
\hline Controlled hypertension & $66.03(59.80)$ & $62.90(9.56)$ \\
\hline Controlled diabetes & $68.19(8.40)$ & $67.54(10.42)$ \\
\hline Diabetes Prevalence (County) & $0.0933(0.0203)$ & $0.1027(0.0242)$ \\
\hline HIV Prevalence (County) & $\begin{array}{c}518.6 \\
(643.1)\end{array}$ & 358.4 (412.1) \\
\hline Health Centers (n) & 22 & 968 \\
\hline
\end{tabular}

Abbreviations: THC, teaching health center; FTE, full-time equivalent; APC, advanced practice clinicians; MH, mental health; SUD, substance use disorder; FQHC, federally qualified health center.

to $\$ 229,903$ (median $\$ 67,892$ ) for a full fiscal year.

\section{Discussion}

Community-based residency programs are an important strategy to increase the primary care workforce for underserved communities. However, as health centers consider whether or not to engage in training, they must consider the balance of costs and benefits in starting and maintaining residency programs, including the potential impact on patient service, quality, and related revenue. Our findings support previous qualitative reports of increased staffing, patient service, and quality of care related to residency training. We found health centers that started new THC residency programs saw increased physician and nurse recruitment, total patient visits, visits for substance use disorders and depression, and slightly improved low-birth-weight outcomes over the study period compared to non-THC health centers.

Teaching health centers also saw a decrease in physician productivity (visits per provider), which might naturally be of concern for health centers. However, this decrease in physician productivity reflects, in part, the inclusion of residents in the overall physician FTE used in determining visits per provider. Resident physicians generally see fewer patients per clinical session, particularly in their earlier years of training. As we were unable to differentiate the number of resident FTE included in the overall health center physician FTE due to data limitations, we could not determine the productivity of solely nonresident physicians and any related impact on net costs. Residency programs are known to be associated with additional training costs. An evaluation of the THC program found a median net cost per resident of $\$ 157,602$, in FY 2017 dollars..$^{18}$ Another study of family medicine residency programs estimated the cost per resident in 2016 to be $\$ 179,353 .{ }^{19}$ Both studies accounted for resident-associated patient revenue in the net cost of residency training. The cost of residency programs and the potential impact on physician productivity highlight the importance of GME funding to support community-based residency programs.

Our examination of the FQHC cost reports confirms that very few health centers directly submit for Medicare GME support, and the level of this support is minimal. While Medicare GME provided teaching hospitals an estimated $\$ 12.5$ billion in GME payments in $2015,{ }^{20}$ only 13 FQHCs submitted cost reports with calculated qualifying direct GME costs, ranging from $\$ 6$ to $\$ 229,903$.

The THC program is currently funded at $\$ 126.5$ million annually. However, the THC program has faced significant financial instability. Initially funded for 5 years, Congress has extended the program in approximately 2-year intervals since 2015 , often with last-minute and shorter-term funding extensions creating significant challenges for ongoing primary care residency programs that require 3 to 4 years of training. There are currently 63 THC residency programs, with seven newly-awarded THCs in 2020. This was the first set of newly-awarded THCs since 2014. The recent American Rescue Plan demonstrated interest and support for these community-based primary care residency programs, providing an additional $\$ 330$ million to the program. ${ }^{21}$ However, the funding is one-time funding, which will present future sustainability challenges for the THC programs. 
Table 3: FTEs of Providers at New Teaching Health Centers Compared to Other Health Centers

\begin{tabular}{|c|c|c|c|c|c|c|c|c|}
\hline & $\begin{array}{l}\text { Physician } \\
\text { (SE) }\end{array}$ & APC (SE) & $\begin{array}{c}\text { Nurse } \\
\text { (SE) }\end{array}$ & $\begin{array}{c}\text { Other } \\
\text { Medical } \\
\text { (SE) }\end{array}$ & $\begin{array}{c}\text { MH/SUD } \\
\text { (SE) }\end{array}$ & $\begin{array}{l}\text { Total Visits } \\
\text { (SE) }\end{array}$ & $\begin{array}{l}\text { Physician } \\
\text { Visits/ } \\
\text { FTE (SE) }\end{array}$ & $\begin{array}{c}\text { Total Medica } \\
\text { Visits/ } \\
\text { FTE (SE) }\end{array}$ \\
\hline New THC & $\begin{array}{c}16.40 * * \\
(3.824)\end{array}$ & $\begin{array}{c}2.550 \\
(2.356)\end{array}$ & $\begin{array}{c}6.456 \\
(4.880)\end{array}$ & $\begin{array}{c}13.47 \\
(7.356)\end{array}$ & $\begin{array}{c}3.742 \\
(3.487)\end{array}$ & $\begin{array}{c}46,194 \\
(27,554)\end{array}$ & $\begin{array}{c}-425.3^{* * *} \\
(104.9)\end{array}$ & $\begin{array}{l}-165.6 \\
(93.70)\end{array}$ \\
\hline Rural & $\begin{array}{c}-10.97 * * \\
(2.484)\end{array}$ & $\begin{array}{c}-4.698 * * \\
(1.542)\end{array}$ & $\begin{array}{c}-8.656^{* * *} \\
(2.940)\end{array}$ & $\begin{array}{c}-13.31^{* * *} \\
(5.128)\end{array}$ & $\begin{array}{c}-6.966^{* * *} \\
(2.361)\end{array}$ & $\begin{array}{c}-46,031^{*} \\
(18,837)\end{array}$ & $\begin{array}{c}257.3^{* *} * \\
(96.20)\end{array}$ & $\begin{array}{c}298.0^{* * *} \\
(69.40)\end{array}$ \\
\hline Age over 65 years & $\begin{array}{c}13.16 \\
(11.70)\end{array}$ & $\begin{array}{l}-12.48 \\
(8.055)\end{array}$ & $\begin{array}{c}26.87 \\
(16.33)\end{array}$ & $\begin{array}{l}-23.28 \\
(23.93)\end{array}$ & $\begin{array}{c}-7.292 \\
(14.66)\end{array}$ & $\begin{array}{c}-8,307 \\
(89,505)\end{array}$ & $\begin{array}{c}267.2 \\
(804.2)\end{array}$ & $\begin{array}{c}-613.7 \\
(560.7)\end{array}$ \\
\hline Female & $\begin{array}{c}40.21^{* *} \\
(9.027)\end{array}$ & $\begin{array}{c}30.44^{* *} \\
(5.910)\end{array}$ & $\begin{array}{c}35.43^{* *} \\
(12.05)\end{array}$ & $\begin{array}{c}81.11^{* *} \\
(17.63)\end{array}$ & $\begin{array}{c}-18.17 \\
(15.14)\end{array}$ & $\begin{array}{c}223,980^{* * *} \\
(60,789)\end{array}$ & $\begin{array}{c}2,370 * * \\
(600.4)\end{array}$ & $\begin{array}{c}2,239 * * \\
(449.2)\end{array}$ \\
\hline Medicaid & $\begin{array}{l}13.16^{*} \\
(6.252)\end{array}$ & $\begin{array}{c}7.393 \\
(4.618)\end{array}$ & $\begin{array}{c}3.216 \\
(9.793)\end{array}$ & $\begin{array}{c}44.99 * * \\
(14.81)\end{array}$ & $\begin{array}{c}14.15 \\
(10.21)\end{array}$ & $\begin{array}{c}132,449^{*} \\
(56,965)\end{array}$ & $\begin{array}{l}974.6^{*} \\
(449.3)\end{array}$ & $\begin{array}{l}636.5^{*} \\
(267.7)\end{array}$ \\
\hline Poverty & $\begin{array}{c}-11.70^{* * *} \\
(4.258)\end{array}$ & $\begin{array}{l}-3.223 \\
(2.728)\end{array}$ & $\begin{array}{c}-1.356 \\
(5.812)\end{array}$ & $\begin{array}{c}-12.84 \\
(8.441)\end{array}$ & $\begin{array}{c}-4.691 \\
(4.699)\end{array}$ & $\begin{array}{c}-34,266 \\
(30,317)\end{array}$ & $\begin{array}{c}237.2 \\
(142.0)\end{array}$ & $\begin{array}{c}126.2 \\
(117.9)\end{array}$ \\
\hline $\begin{array}{l}\text { English primary } \\
\text { language }\end{array}$ & $\begin{array}{l}14.77^{* * *} \\
(5.207)\end{array}$ & $\begin{array}{l}6.554^{*} \\
(3.017) \\
\end{array}$ & $\begin{array}{c}2.710 \\
(6.051)\end{array}$ & $\begin{array}{c}38.33^{* *} \\
(9.898) \\
\end{array}$ & $\begin{array}{c}2.368 \\
(5.034) \\
\end{array}$ & $\begin{array}{c}112,735^{* *} \\
(38,378)\end{array}$ & $\begin{array}{c}659.9 * * \\
(249.9) \\
\end{array}$ & $\begin{array}{c}642.4^{* * *} \\
(194.0)\end{array}$ \\
\hline Black & $\begin{array}{c}-13.99 * * \\
(4.830)\end{array}$ & $\begin{array}{c}-9.231^{* * *} \\
(2.496)\end{array}$ & $\begin{array}{l}-11.60^{*} \\
(4.962)\end{array}$ & $\begin{array}{c}-17.96^{*} \\
(7.144) ß\end{array}$ & $\begin{array}{c}-13.84^{* *} \\
(4.211)\end{array}$ & $\begin{array}{c}-99,514^{* *} \\
(30,229)\end{array}$ & $\begin{array}{c}-235.5 \\
(189.1)\end{array}$ & $\begin{array}{c}-141.2 \\
(138.2)\end{array}$ \\
\hline $\begin{array}{l}\text { Diabetes } \\
\text { prevalence }\end{array}$ & $\begin{array}{l}-24.92 \\
(39.62) \\
\end{array}$ & $\begin{array}{c}12.30 \\
(26.57) \\
\end{array}$ & $\begin{array}{c}2.684 \\
(48.54) \\
\end{array}$ & $\begin{array}{l}-112.4 \\
(92.97) \\
\end{array}$ & $\begin{array}{l}-146.7^{*} \\
(60.26) \\
\end{array}$ & $\begin{array}{l}-277,396 \\
(296,873) \\
\end{array}$ & $\begin{array}{c}642.9 \\
(2,096) \\
\end{array}$ & $\begin{array}{c}1,790 \\
(1,482) \\
\end{array}$ \\
\hline HIV prevalence & $\begin{array}{c}0.00577 \\
(0.00471) \\
\end{array}$ & $\begin{array}{l}0.000598 \\
(0.00301) \\
\end{array}$ & $\begin{array}{l}-0.00245 \\
(0.00718) \\
\end{array}$ & $\begin{array}{c}0.00371 \\
(0.00909) \\
\end{array}$ & $\begin{array}{c}0.00613 \\
(0.00476) \\
\end{array}$ & $\begin{array}{c}18.34 \\
(36.60) \\
\end{array}$ & $\begin{array}{l}-0.180 \\
(0.106) \\
\end{array}$ & $\begin{array}{l}-0.195 * * \\
(0.0756) \\
\end{array}$ \\
\hline Constant & $\begin{array}{l}-10.49 \\
(7.284) \\
\end{array}$ & $\begin{array}{l}-4.638 \\
(4.698) \\
\end{array}$ & $\begin{array}{l}-4.012 \\
(9.566) \\
\end{array}$ & $\begin{array}{l}-17.81 \\
(14.66) \\
\end{array}$ & $\begin{array}{c}36.12^{* * *} \\
(10.70)\end{array}$ & $\begin{array}{l}-32,160 \\
(48,970) \\
\end{array}$ & $\begin{array}{c}678.5 \\
(434.3) \\
\end{array}$ & $\begin{array}{l}670.8^{*} \\
(336.3) \\
\end{array}$ \\
\hline Health centers $(\mathrm{N})$ & 990 & 990 & 990 & 990 & 990 & 990 & 990 & 990 \\
\hline$R^{2}$ & 0.589 & 0.404 & 0.296 & 0.484 & 0.253 & 0.423 & 0.408 & 0.582 \\
\hline
\end{tabular}

Abbreviations: SE, standard error; THC, teaching health center; FTE, full-time equivalent; APC, advanced practice clinicians; MH, mental health; SUD, substance use disorder; FQHC, federally qualified health centers.

$* P<.05$.

*** $P<.01$.

Strategies to increase health center residency programs might include expanding and stabilizing the THC program, enhancing FQHC Medicare GME payments, and supporting training through the Section 330 grants to community health centers. Medicaid GME reform may be another area where federal and state policies can be leveraged to address community health workforce needs. ${ }^{22}$ Our findings suggest these GME reforms would also be consistent with any federal and state goals to expand health center service and quality of care-both overall and in targeted areas such as mental health and maternity care.

Our study has a number of additional limitations. Other health centers may be training residents, but there is no full roster of health centers engaged in residency training programs. Therefore, we were unable to control for this training. Our service and quality outcomes were also limited to measures reported in the health center program UDS. These outcomes may not reflect the full potential impact of residency programs on health centers' service and quality of care. In addition, while the directionality of service and quality outcomes were consistent with qualitative reports of expanded service and improved quality, many areas were not statistically significant. This may be due to the small number of THCs.

Our study finds that while new residency programs are associated with increased provider recruitment, expanded patient service, and improved health outcomes, they are also potentially associated with decreased provider productivity in health centers. These findings suggest residency programs can benefit health centers, but highlights the need for sufficient and stable GME payments to support communitybased primary care residency programs.

FINANCIAL SUPPORT: This study was supported by the Health Resources and Services Administration (HRSA) of the US Department of Health and Human Services (HHS) as part of an award totaling $\$ 450,000$, with $0 \%$ financed by nongovernmental sources. The contents are those of the author(s) and do not necessarily represent the official views of, nor an endorsement by HRSA, HHS, or the US Government. For more information, visit HRSA.gov.

CORRESPONDING AUTHOR: Address correspondence to Dr Candice Chen, MD, MPH, 2175 K St NW, Suite 250, Washington, DC 20037. 202-994-4243. cpchen@gwu.edu. 
Table 4: Total Visits for Service Lines Provided by New Teaching Health Centers Compared to Other Health Centers

\begin{tabular}{|c|c|c|c|c|c|c|}
\hline & SUD (SE) & Alcohol (SE) & Depression (SE) & $\begin{array}{l}\text { Other Mental } \\
\text { Health (SE) }\end{array}$ & $\begin{array}{c}\text { Contraceptives } \\
\text { (SE) }\end{array}$ & $\begin{array}{l}\text { Deliveries } \\
\text { (SE) }\end{array}$ \\
\hline New THC & $\begin{array}{c}175.1 \\
(632.2)\end{array}$ & $\begin{array}{c}126.9 \\
(394.4)\end{array}$ & $\begin{array}{c}5,045 \\
(3,468)\end{array}$ & $\begin{array}{c}2,739 \\
(1,737)\end{array}$ & $\begin{array}{c}1,073 \\
(785.1)\end{array}$ & $\begin{array}{l}231.0^{*} \\
(91.16)\end{array}$ \\
\hline Rural & $\begin{array}{c}-1,632^{* *} \\
(487.8)\end{array}$ & $\begin{array}{l}-703.5^{* * *} \\
(271.9)\end{array}$ & $\begin{array}{l}-5,780^{*} \\
(2,388)\end{array}$ & $\begin{array}{c}-3,432^{* * *} \\
(1,122)\end{array}$ & $\begin{array}{c}-1,454^{* *} \\
(499.9)\end{array}$ & $\begin{array}{c}-216.0 * * \\
(58.39)\end{array}$ \\
\hline Age over 65 years & $\begin{array}{l}-2,488 \\
(2,612)\end{array}$ & $\begin{array}{l}-1,179 \\
(1,422)\end{array}$ & $\begin{array}{c}-100.1 \\
(21,707)\end{array}$ & $\begin{array}{c}10,147 \\
(10,110)\end{array}$ & $\begin{array}{l}-4,991^{*} \\
(2,288)\end{array}$ & $\begin{array}{c}111.5 \\
(265.1)\end{array}$ \\
\hline Female & $\begin{array}{c}-11,375^{* *} \\
(4,347)\end{array}$ & $\begin{array}{l}-6,003^{*} \\
(2,459)\end{array}$ & $\begin{array}{c}9,158 \\
(10,575)\end{array}$ & $\begin{array}{l}-3,598 \\
(4,931)\end{array}$ & $\begin{array}{c}16,269 * * \\
(2,177)\end{array}$ & $\begin{array}{l}1,440 * * \\
(265.9)\end{array}$ \\
\hline Medicaid & $\begin{array}{c}3,476 \\
(1,890) \\
\end{array}$ & $\begin{array}{c}1,013 \\
(871.1) \\
\end{array}$ & $\begin{array}{l}12,970 \\
(8,136) \\
\end{array}$ & $\begin{array}{c}7,605 \\
(4,114) \\
\end{array}$ & $\begin{array}{c}1,349 \\
(1,372) \\
\end{array}$ & $\begin{array}{l}385.2 * \\
(163.6) \\
\end{array}$ \\
\hline Poverty & $\begin{array}{c}422.9 \\
(979.3)\end{array}$ & $\begin{array}{l}-127.2 \\
(469.5)\end{array}$ & $\begin{array}{l}-4,925 \\
(4,290)\end{array}$ & $\begin{array}{l}-1,815 \\
(2,187)\end{array}$ & $\begin{array}{l}-837.6 \\
(898.3)\end{array}$ & $\begin{array}{c}-311.9 * * \\
(112.6)\end{array}$ \\
\hline $\begin{array}{l}\text { English primary } \\
\text { language }\end{array}$ & $\begin{array}{c}-3,145^{* *} \\
(1,042) \\
\end{array}$ & $\begin{array}{l}-1,092^{*} \\
(510.0)\end{array}$ & $\begin{array}{l}-5,143 \\
(4,789) \\
\end{array}$ & $\begin{array}{c}1,988 \\
(2,142) \\
\end{array}$ & $\begin{array}{c}3,661^{* * *} \\
(994.4)\end{array}$ & $\begin{array}{l}491.2 * * \\
(122.6)\end{array}$ \\
\hline Black & $\begin{array}{l}-1,995 \\
(1,044) \\
\end{array}$ & $\begin{array}{l}-728.0 \\
(427.4) \\
\end{array}$ & $\begin{array}{c}-16,645^{* * *} \\
(3,950)\end{array}$ & $\begin{array}{c}-7,222^{* *} \\
(1,831)\end{array}$ & $\begin{array}{c}-2,408^{* *} \\
(802.3)\end{array}$ & $\begin{array}{c}-352.9 * * \\
(108.5)\end{array}$ \\
\hline $\begin{array}{l}\text { Diabetes } \\
\text { prevalence }\end{array}$ & $\begin{array}{l}-19,886 \\
(12,939) \\
\end{array}$ & $\begin{array}{c}-16,273^{*} \\
(8,188) \\
\end{array}$ & $\begin{array}{l}-105,059 \\
(58,014) \\
\end{array}$ & $\begin{array}{l}-31,545 \\
(21,749) \\
\end{array}$ & $\begin{array}{c}-17,572 * \\
(8,393) \\
\end{array}$ & $\begin{array}{c}373.4 \\
(989.5) \\
\end{array}$ \\
\hline HIV prevalence & $\begin{array}{c}1.531 \\
(1.157) \\
\end{array}$ & $\begin{array}{c}0.332 \\
(0.518) \\
\end{array}$ & $\begin{array}{c}1.363 \\
(4.529) \\
\end{array}$ & $\begin{array}{c}1.402 \\
(2.525) \\
\end{array}$ & $\begin{array}{c}0.731 \\
(1.013) \\
\end{array}$ & $\begin{array}{l}0.0382 \\
(0.102) \\
\end{array}$ \\
\hline Constant & $\begin{array}{c}10,471^{* *} \\
(3,104)\end{array}$ & $\begin{array}{c}6,376^{* * *} \\
(1,629)\end{array}$ & $\begin{array}{c}20,101^{*} \\
(9,551)\end{array}$ & $\begin{array}{l}7,608^{*} \\
(3,786)\end{array}$ & $\begin{array}{c}-4,677 * * \\
(1,506)\end{array}$ & $\begin{array}{c}-698.6^{* * *} \\
(197.9)\end{array}$ \\
\hline $\begin{array}{l}\text { Health centers } \\
(\mathrm{N})\end{array}$ & 990 & 990 & 990 & 990 & 990 & 990 \\
\hline$R^{2}$ & 0.206 & 0.215 & 0.234 & 0.255 & 0.530 & 0.665 \\
\hline
\end{tabular}

Robust standard errors in parentheses

Abbreviations: SE, standard error; THC, teaching health center; FTE, full-time equivalent; APC, advanced practice clinicians; MH, mental health; SUD, substance use disorder; FQHC, federally qualified health centers.

$* P<.05$.

*** $P<.01$.

Table 5: Outcome Measure for Hypertension, Diabetes, and Low Birth Weight of New Teaching Health Centers Compared to Other Health Centers

\begin{tabular}{|c|c|c|c|c|}
\hline & $\begin{array}{c}\text { Controlled } \\
\text { Hypertension (SE) }\end{array}$ & $\begin{array}{c}\text { Controlled } \\
\text { Diabetes (SE) }\end{array}$ & $\begin{array}{l}\text { Low Birth } \\
\text { Weight (SE) }\end{array}$ & $\begin{array}{c}\text { Early Entry Into } \\
\text { Prenatal Care (SE) }\end{array}$ \\
\hline New THC & $\begin{array}{l}-0.0203 \\
(0.0132)\end{array}$ & $\begin{array}{c}0.0113 \\
(0.0126)\end{array}$ & $\begin{array}{l}-0.00820 \\
(0.00502)\end{array}$ & $\begin{array}{l}0.0490^{* * *} \\
(0.0188)\end{array}$ \\
\hline Rural & $\begin{array}{r}-0.000893 \\
(0.00906) \\
\end{array}$ & $\begin{array}{l}-0.00474 \\
(0.00824) \\
\end{array}$ & $\begin{array}{c}0.00726 \\
(0.00488)\end{array}$ & $\begin{array}{c}0.0228 \\
(0.0146)\end{array}$ \\
\hline Age over 65 years & $\begin{array}{c}0.144^{*} \\
(0.0702)\end{array}$ & $\begin{array}{l}0.485^{* * *} \\
(0.0888)\end{array}$ & $\begin{array}{l}-0.0367 \\
(0.0520)\end{array}$ & $\begin{array}{l}0.346^{*} \\
(0.144)\end{array}$ \\
\hline Female & $\begin{array}{l}0.290 * * \\
(0.0643)\end{array}$ & $\begin{array}{c}0.152 \\
(0.0879)\end{array}$ & $\begin{array}{c}0.0217 \\
(0.0561)\end{array}$ & $\begin{array}{c}0.210 \\
(0.161)\end{array}$ \\
\hline Medicaid & $\begin{array}{c}0.0482 \\
(0.0362)\end{array}$ & $\begin{array}{c}0.0632 \\
(0.0368)\end{array}$ & $\begin{array}{c}0.0211 \\
(0.0222)\end{array}$ & $\begin{array}{c}0.0975 \\
(0.0547)\end{array}$ \\
\hline Poverty & $\begin{array}{c}0.0110 \\
(0.0149)\end{array}$ & $\begin{array}{l}0.00822 \\
(0.0185)\end{array}$ & $\begin{array}{c}0.000819 \\
(0.0100)\end{array}$ & $\begin{array}{c}0.0377 \\
(0.0267)\end{array}$ \\
\hline
\end{tabular}


Table 5: Continued

\begin{tabular}{|l|c|c|c|c|}
\hline & $\begin{array}{c}\text { Controlled } \\
\text { Hypertension (SE) }\end{array}$ & $\begin{array}{c}\text { Controlled } \\
\text { Diabetes (SE) }\end{array}$ & $\begin{array}{c}\text { Low Birth } \\
\text { Weight (SE) }\end{array}$ & $\begin{array}{c}\text { Early Entry Into } \\
\text { Prenatal Care (SE) }\end{array}$ \\
\hline English primary language & $-0.0323(0.0255)$ & $0.0275(0.0190)$ & $-0.00390(0.0107)$ & $-0.0658^{*}(0.0304)$ \\
\hline Black & $-0.147^{* *}(0.0209)$ & $-0.146^{* *}(0.0249)$ & $0.0804^{* *}(0.0124)$ & $-0.189^{* *}(0.0329)$ \\
\hline Diabetes prevalence & $-0.117(0.222)$ & $0.0821(0.214)$ & $0.0912(0.129)$ & $0.588(0.360)$ \\
\hline HIV prevalence & $-1.71 \mathrm{e}-07(1.56 \mathrm{e}-05)$ & $1.92 \mathrm{e}-05(1.16 \mathrm{e}-05)$ & $-1.13 \mathrm{e}-05^{*}(5.59 \mathrm{e}-06)$ & $2.72 \mathrm{e}-05(1.51 \mathrm{e}-05)$ \\
\hline Constant & $0.482^{* *}(0.0427)$ & $0.517^{* *}(0.0632)$ & $0.0391(0.0348)$ & $0.502^{* *(0.108)}$ \\
\hline Health centers (N) & 990 & 990 & 638 & 638 \\
\hline$R^{2}$ & 0.345 & 0.307 & 0.444 & 0.455 \\
\hline
\end{tabular}

Abbreviations: SE, standard error; THC, teaching health center; FTE, full-time equivalent; APC, advanced practice clinicians; MH, mental health; SUD, substance use disorder; FQHC, federally qualified health center.

$* P<.05$.

*** $P<.01$.

\section{References}

1. Shortage Areas. Health Resources and Services Administration. Data updated June 16, 2021. Accessed June 16, 2021. https://data. hrsa.gov/topics/health-workforce/shortageareas

2. Staffing the Safety Net: Building the Primary Care Workforce at America's Health Centers. Bethesda, MD: National Association of Community Health Centers; March 2016. Accessed Jul 27, 2020. http://www.nachc.org/ wp-content/uploads/2015/10/NACHC_Workforce_Report_2016.pdf

3. Morris CG, Johnson B, Kim S, Chen F. Training family physicians in community health centers: a health workforce solution. Fam Med. 2008;40(4):271-276.

4. Phillips RL, Petterson S, Bazemore A. Do residents who train in safety net settings return for practice? Acad Med. 2013;88(12):19341940. doi:10.1097/ACM.0000000000000025

5. Goodfellow A, Ulloa JG, Dowling PT, et al. Predictors of Primary Care Physician Practice Location in Underserved Urban or Rural Areas in the United States: A Systematic Literature Review. Acad Med. 2016;91(9):13131321. doi:10.1097/ACM.0000000000001203

6. Lee M, Newton H, Smith T, et al. The Benefits of Physician Training Programs for Rural Communities: Lessons Learned from the Teaching Health Center Graduate Medical Education Program. J Health Care Poor Underserved. 2016;27(4A):83-90. doi:10.1353/ hpu.2016.0184

7. Morris CG, Chen FM. Training residents in community health centers: facilitators and barriers. Ann Fam Med. 2009;7(6):488-494 doi:10.1370/afm.1041

8. Preparing Physicians to Care for Underserved Patients: A Look at California's Teaching Health Centers. Oakland, CA: California Health Care Foundation; August 2016. Accessed July 27, 2020. https:// healthforce.ucsf.edu/sites/healthforce. ucsf.edu/files/publication-pdf/PDF $\% 20$ PreparingTeachingHealthCenters.pdf
9. Education Health Center Guide. Education Health Center Initiative. Published March 4, 2020. Accessed July 29 2020. https://static1.squarespace.com/ static/5996f966e4fcb50cf8969259/t/5e8e1bd e4f1db6340d0b3310/1586371565002/Edu+ Health+Ctr+Guide+FINAL+03+20.pdf

10. Nuss MA, Robinson B, Buckley PF. A statewide strategy for expanding graduate medical education by establishing new teaching hospitals and residency programs. Acad Med. 2015;90(9):1264-1268. doi:10.1097/ ACM.0000000000000803

11. Ben-Ari R, Robbins RJ, Pindiprolu S, Goldman A, Parsons PE. The costs of training internal medicine residents in the United States. Am J Med. 2014;127(10):1017-1023. doi:10.1016/j.amjmed.2014.06.040

12. Blanchard J, Petterson S, Bazemore A Watkins K, Mullan F. Characteristics and distribution of graduate medical education training sites: are we missing opportunities to meet US health workforce needs? Acad Med. 2016;91(10):1416-1422. doi:10.1097/ ACM.0000000000001184

13. Morris CG, Lesko SE, Andrilla HA, Chen FM. Family medicine residency training in community health centers: a national survey. Acad Med. 2010;85(10):1640-1644. doi:10.1097/ACM.0b013e3181f08e2b

14. Bureau of Health Workforce Clinician Dashboards. Health Resources and Services Administration. Accessed July 26, 2020. https:/ data.hrsa.gov/topics/health-workforce/clinician-dashboards

15. Teaching Health Center Graduate Medical Education (THCGME) Program. Health Resources and Services Administration. July 2020. Accessed July 26, 2020. https://bhw. hrsa.gov/grants/medicine/thcgme

16. Teaching Health Center Graduate Medical Education Program: Academic Year 20182019. Health Resources and Services Administration. Accessed July 26, 2020. https://bhw. hrsa.gov/sites/default/files/bhw/health-workforce-analysis/program-highlights/2019-2020/ teaching-health-center-graduate-medicaleducation-program-2019.pdf
17. Levin Z, Meyers P, Peterson L, Habib A, Bazemore A. Practice intentions of family physicians trained in teaching health centers: the value of community-based training. J Am Board Fam Med. 2019;32(2):134-135. doi:10.3122/jabfm.2019.02.180292

18. Regenstein M, Nocella K, Jewers MM, Mullan $\mathrm{F}$. The cost of residency training in teaching health centers. N Engl J Med. 2016;375(7):612-614. doi:10.1056/ NEJMp1607866

19. Pauwels J, Weidner A. The cost of family medicine residency training: impacts of federal and state funding. Fam Med. 2018;50(2):123-127. doi:10.22454/ FamMed.2018.844856

20. Chen C, Chung Y, Petterson S, Bazemore A Changes and variation in medicare graduate medical education payments. JAMA Intern Med. 2020;180(1):148-150. doi:10.1001/jamainternmed.2019.4429

21. American Rescue Plan Act of 2021, HR 1319, 117th Congress (2021). Accessed June 16, 2021. https://www.congress.gov/bill/117thcongress/house-bill/1319/text

22. Fraher EP, Spero J, Bacon T. State-based approaches to reforming medicaid-funded graduate medical education. Chapel Hill, NC: Carolina Health Workforce Research Center. January 2017. Accessed August 1, 2020. https://www.shepscenter.unc.edu/wpcontent/uploads/2017/01/ExecSumm_FraherGME_y3_final-1.pdf 